\title{
Gonadotrophin-inhibiting activity in seminal plasma from intact and vasectomized bulls
}

\author{
J. C. Peek and W. B. Watkins \\ Postgraduate School of Obstetrics and Gynaecology, University of Auckland, Auckland, \\ New Zealand
}

\begin{abstract}
Summary. Bull seminal plasma administered to male rats at the time of castration inhibited the rise in the levels of FSH and LH otherwise seen in the serum $24 \mathrm{~h}$ later. That the gonadotrophin-inhibiting activity was also present in the seminal plasma from vasectomized bulls suggests that it was not of testicular origin. Although the substance with gonadotrophin-inhibiting activity was a protein, it may be chemically distinct from inhibin.
\end{abstract}

\section{Introduction}

Inhibin was the name given by McCullagh (1932) to a testicular hormone that would regulate the secretion of follicle-stimulating hormone (FSH) by negative feedback. Various tissues and secretions of the male reproductive tract, including testicular extracts (bovine: Keogh et al., 1976; ovine: Nandini, Lipner \& Moudgal, 1976; Moodbidri, Joshi \& Sheth, 1976; human: Chari, Hopkinson, Fritze, Sturm \& Hirschhauser, 1977; rat: Le Lannou \& Chambon, 1977), epididymal extracts (rat: Le Lannou \& Chambon, 1977), rete testis fluid (ovine: Setchell \& Jacks, 1974; Blanc \& Dacheux, 1976; Franchimont et al., 1976; Davies, Main, Young \& Setchell, 1976), seminal plasma (bovine: Franchimont, Chari, \& Duraiswami, 1975a; human: Franchimont, 1974) and sperm extracts (bovine: Lugaro, Casellato, Mazzola, Fachini \& Carrea, 1974), contain FSH-suppressing activity which has been attributed to inhibin. Other evidence for inhibin comes from studies of selective damage to the germinal epithelium in which blood levels of FSH are elevated, while luteinizing hormone (LH) levels are often normal or only slightly elevated (Amatayakul, Ryan, Uozumi \& Albert, 1971; Swerdloff, Walsh, Jacobs \& Odell, 1971; Debeljuk, Arimura \& Schally, 1973; Gomes, Hall, Jain \& Boots, 1973; Rich \& de Kretser, 1977), and from the secretion of FSH-inhbiting activity from cultured Sertoli cells (Steinberger \& Steinberger, 1976).

The above evidence suggests the origin of inhibin and its route to the general circulation. Inhibin would be synthesized in the Sertoli cells, perhaps in conjunction with the spermatogonia or spermatids, would be secreted into the seminiferous tubules and transported in the rete testis fluid to the head of the epididymis, where it would be absorbed along with most of the rete testis fluid (Franchimont, Chari, Hagelstein \& Duraiswami, 1975b; Chari, 1977). The presence of FSH-inhibiting activity in seminal plasma could arise from incomplete absorption of inhibin in the epididymis (Franchimont et al., 1975b). We have tested this hypothesis by measuring the amount of FSH-inhibiting activity in seminal plasma from intact and vasectomized bulls. A preliminary account of this work has been presented (Peek \& Watkins, 1978).

\section{Materials and Methods}

Bull seminal plasma was obtained from the New Zealand Dairy Board Artificial Breeding Centre, Newstead, Hamilton, and was stored at $-20^{\circ} \mathrm{C}$ until use. The seminal plasma from intact bulls was a pool of samples from 20 animals of good fertility. The seminal plasma from vasectomized bulls was a pooled sample from 5 bulls vasectomized over 1 year earlier. Indivi- 
dual samples of seminal plasma were obtained from another 4 vasectomized bulls. All vasectomized animals were of proven fertility before vasectomy, but were not used for breeding because of genetic reasons.

Protein was precipitated from seminal plasma at $4^{\circ} \mathrm{C}$ by the addition of absolute ethanol to a concentration of $86 \%(\mathrm{v} / \mathrm{v})$ (Franchimont et al., 1975a). The precipitate was removed by centrifugation at $3000 \mathrm{~g}$ for $10 \mathrm{~min}$ and freeze-dried. This procedure gave 80 and $46 \mathrm{mg}$ pale yellow powder $/ \mathrm{ml}$ seminal plasma from intact and vasectomized bulls respectively.

Solutions of the seminal plasma extracts (I from intact and V from vasectomized bulls) were heated and digested with pepsin to denature the protein. The heat treatment for $400 \mathrm{mg}$ Extract I and $230 \mathrm{mg}$ Extract $\mathrm{V}$ consisted of dissolution in $10 \mathrm{ml}$ saline $(9 \mathrm{~g} \mathrm{NaCl} / \mathrm{l})$ and heating in a water bath at $67^{\circ} \mathrm{C}$ for $1 \mathrm{~h}$. The solutions were then snap-frozen and stored at $-20^{\circ} \mathrm{C}$. For pepsin digestion, $400 \mathrm{mg}$ Extract $\mathrm{I}$ or $230 \mathrm{mg}$ Extract $\mathrm{V}$ were dissolved in $10 \mathrm{ml} 0.2 \mathrm{M}$-glycine$\mathrm{HCl}$ buffered at $\mathrm{pH}$ 2, and $1 \mathrm{mg}$ pepsin (Sigma Chemical Co., St. Louis, Missouri) was added per $50 \mathrm{mg}$ extract. The solutions were incubated at $37^{\circ} \mathrm{C}$ for $24 \mathrm{~h}$, the $\mathrm{pH}$ was then brought to 7.5 with $2 \mathrm{M}$-sodium hydroxide, and the solutions were snap-frozen and stored at $-20^{\circ} \mathrm{C}$.

FSH- and LH-inhibiting activity were detected by the suppression of the post-castration rise of serum levels of FSH and LH in (1) pubertal rats (Nandini et al., 1976; Davies et al., 1976) or (2) chronically castrated adult rats (Setchell \& Jacks, 1974; Franchimont et al., 1975a). For Test 1, 5-week-old Sprague-Dawley rats were castrated through a scrotal incision, under penthrane-nitrous oxide anaesthesia. The material to be assayed was administered in a single intraperitoneal injection while the animal was still anaesthetized. Seminal plasma samples were diluted to $0.5 \mathrm{ml}$ with saline; Extracts I and V were dissolved in 0.5 or $1.0 \mathrm{ml}$ saline while the heated and pepsin-treated extracts were injected undiluted. The rats were bled after decapitation 23-25 h later.

For Test 2, Sprague-Dawley rats weighing 200-300 g were castrated 3 weeks before treatment, which consisted of daily intraperitoneal injections of up to $1.0 \mathrm{ml}$ seminal plasma from intact bulls for 2-4 days. The rats were bled at decapitation 4 or $24 \mathrm{~h}$ after the last injection.

FSH and LH concentrations in $100 \mu$ and $200 \mu$ aliquots of serum were measured by radioimmunoassay using the reagents and method supplied by the NIAMD Rat Hormone Program. The sensitivity of the LH and FSH assays were $4 \mathrm{ng}$ LH-RP1 and $30 \mathrm{ng}$ FSH-RP1 respectively. Samples with $\mathrm{LH}$ concentrations below $20 \mathrm{ng} / \mathrm{ml}$ were assigned a concentration of $20 \mathrm{ng} / \mathrm{ml}$ for statistical analysis. The interassay coefficient of variation was $10.9 \%$ for $\mathrm{FSH}$ and $12.0 \%$ for $\mathrm{LH}$, while the average intra-assay coefficient of variation was $6.3 \%$ for $\mathrm{FSH}$ and $5.3 \%$ for $\mathrm{LH}$. To reduce error, samples from a single experiment were assayed together.

Hormone concentrations were assumed to be log-normally distributed. The one-tailed Student's $t$ test was applied to the logarithmically transformed data to detect whether treatment groups had means significantly lower than the mean of the control groups receiving saline.

\section{Results}

When seminal plasma from intact bulls was administered to male rats at the time of castration (Test 1), the rise in serum concentrations of FSH and LH otherwise seen $24 \mathrm{~h}$ later was inhibited. The degree of inhibition was clearly related to the amount of seminal plasma given (Table 1a). At a dose of $0.5 \mathrm{ml}, \mathrm{FSH}$ and $\mathrm{LH}$ levels were always significantly lower than those of the control group receiving saline; for $\mathrm{FSH}, P<0.005$ in all of 14 separate experiments, and for $\mathrm{LH}$, $P<0.05$ in all of the 14 experiments and $P<0.005$ in 10 of the 14 experiments. Rats receiving $0.5 \mathrm{ml}$ seminal plasma usually had FSH and LH concentrations comparable to those of intact animals. At a dose of $0.2 \mathrm{ml}$, FSH levels were significantly $(P<0.05)$ lowered in 3 of 5 experiments, and LH levels in 2 of 5 experiments. In contrast, the rats in Test 2, castrated 3 weeks before the onset of treatment with seminal plasma from intact bulls, did not show any lowering of FSH or LH levels. 
Seminal plasma from vasectomized bulls also inhibited the post-castration rise of FSH and LH levels in Test 1 (Table $1 b$ ) and, moreover, to the same extent as did the seminal plasma from intact bulls. A $0.5 \mathrm{ml}$ volume of the pooled or individual samples always significantly $(P<0.05)$ suppressed FSH and $\mathrm{LH}$ values near to those of intact rats, while a dose of $0.2 \mathrm{ml}$ sometimes caused a significant suppression.

Table 1. Inhibition of the post-castration rise of FSH and LH in acutely castrated male rats by the administration of graded doses of seminal plasma

\begin{tabular}{cccc}
\hline Treatment & No. of rats & FSH $(\mathrm{ng} / \mathrm{ml})$ & LH $(\mathrm{ng} / \mathrm{ml})$ \\
\hline (a) Intact bulls & & & \\
0 (saline controls) & 7 & $1161(1102-1225)$ & $135(124-150)$ \\
$0.1 \mathrm{ml}$ & 4 & $1435(1287-1600)$ & $63(49-83)^{* *}$ \\
$0.2 \mathrm{ml}$ & 4 & $843(673-1056)$ & $41(29-58)^{* *}$ \\
$0.5 \mathrm{ml}$ & 4 & $396(368-425)^{* *}$ & $<20^{* *}$ \\
(b) Vasectomized bulls & & & \\
0 (saline controls) & 5 & $1119(1029-1219)$ & $479(367-624)$ \\
$0.1 \mathrm{ml}$ & 4 & $840(738-955)^{*}$ & $298(261-340)$ \\
$0.2 \mathrm{ml}$ & 4 & $563(504-630)^{* *}$ & $173(162-184)^{*}$ \\
$0.5 \mathrm{ml}$ & 4 & $421(374-474)^{* *}$ & $64(47-99)^{* *}$ \\
\hline
\end{tabular}

Values are the geometric mean and its $66 \%$ confidence interval.

Significantly different from control group; ${ }^{*} P<0.05,{ }^{* *} P<0.005$.

Table 2. Effect of heat and pepsin treatment on the FSH- and LH-inhibiting activity of Extracts I and V

\begin{tabular}{cccc}
\hline Treatment & No. of rats & FSH $(\mathrm{ng} / \mathrm{ml})$ & LH $(\mathrm{ng} / \mathrm{ml})$ \\
\hline (a) Extract I & & & \\
0 (saline control) & 8 & $1205(1128-1286)$ & $220(191-252)$ \\
$40 \mathrm{mg}$ & 5 & $579(478-700)^{* *}$ & $40(26-63)^{* *}$ \\
Heat-treated & 7 & $1173(1063-1295)$ & $144(111-187)$ \\
Pepsin-treated & 7 & $1115(996-1249)$ & $125(86-182)$ \\
(b) Extract V & & & \\
0 (saline control) & 9 & $1580(1510-1652)$ & $221(193-254)$ \\
$23 \mathrm{mg}$ & 9 & $661(566-772)^{* *}$ & $69(50-95)^{* *}$ \\
Heat-treated & 10 & $1484(1382-1593)$ & $315(292-341)$ \\
Pepsin-treated & 9 & $1555(1403-1725)$ & $231(185-288)$ \\
(c) Extract I & & & \\
0 (saline control) & 9 & $1580(1510-1652)$ & $221(193-254)$ \\
$40 \mathrm{mg}$ & 8 & $669(578-775)^{* *}$ & $50(41-61)^{* *}$ \\
Incubation at $37^{\circ} \mathrm{C}$ & 8 & $754(648-876)^{* *}$ & $76(54-106)^{* *}$ \\
pH 2, for $24 \mathrm{~h}$ & & & \\
\hline
\end{tabular}

Values are the geometric mean and its $66 \%$ confidence interval.

Significantly different from control group; ${ }^{* *} P<0.005$.

The FSH- and LH-inhibiting activity was extracted from seminal plasma by adding cold ethanol to precipitate protein. The activity of Extracts I and $\mathrm{V}$ was lost after heating at $67^{\circ} \mathrm{C}$ for $1 \mathrm{~h}$ and after incubation with pepsin (Table $2 \mathrm{a}$ and $2 \mathrm{~b}$ ). The loss of activity after pepsin digestion was not due to prolonged heating at $37^{\circ} \mathrm{C}$. The activity was retained when Extract I was subjected to the conditions of pepsin incubation, but in the absence of pepsin itself (Table $2 \mathrm{c}$ ).

\section{Discussion}

These results demonstrate that seminal plasma from intact and vasectomized bulls is able to inhibit the post-castration rise of FSH and $\mathrm{LH}$ in acutely castrated male rats. This gonadotrophin-inhibiting activity has some properties in common with the FSH-suppressing activity in 
bull seminal plasma described by Franchimont et al. (1975a) and recently purified and called "bSP-inhibin" by Chari, Duraiswami \& Franchimont (1978). The activity in seminal plasma from intact bulls can be precipitated by ethanol, is destroyed by pepsin digestion and preliminary studies show that its chromatographic behaviour on Sephadex G-75 gels eluted with $0.05 \mathrm{M}$-sodium acetate buffer, $\mathrm{pH} 4$, and with $4 \mathrm{M}$-urea-0.05 $\mathrm{M}$-sodium acetate buffer, $\mathrm{pH} 4$, is also similar (J. C. Peek \& W. B. Watkins, unpublished observations). However, the gonadotrophin-inhibiting activity we have observed in bull seminal plasma has some properties different from those attributed to inhibin. Foremost is its property of suppressing both FSH and LH.

The degree to which material considered to contain inhibin exhibits FSH suppression without accompanying LH suppression varies. For instance, Nandini et al. (1976) found that extracts of ram testes suppressed only FSH when given within 12-24 h of castration to 35-day-old rats, while Davies et al. (1976), also using acutely castrated 35-day-old rats but a different treatment regimen, reported that extracts from ram rete testis fluid suppressed only FSH at lower doses, but FSH and LH at higher doses. Baker et al. (1976) have found that fractions of bull testis homogenates that suppressed FSH alone in sheep suppressed both FSH and LH in intact rats. Such variation may be due to differences in the methods used to detect FSH and LH suppression, or in the material under study. Chari et al. (1978) have shown that intravenous injection of freshly prepared "bSP-inhibin" into acutely castrated 35-day-old rats caused suppression of FSH alone, while material which had been stored at $-20^{\circ} \mathrm{C}$ for 6 weeks suppressed both FSH and $\mathrm{LH}$. The seminal plasma samples used in the present study were stored at $-20^{\circ} \mathrm{C}$ for more than 6 weeks before they were used.

The failure of seminal plasma from intact bulls to suppress FSH or LH in chronically castrated male rats, the assay originally used by Franchimont et al. (1975a), might be explained by a change in the nature of the response with time after castration (Davies et al., 1976; Hopkinson, Fritze, Chari, Sturm \& Hirschhauser, 1977). As yet, we cannot be certain that the gonadotrophin-inhibiting activity observed here is the same as the "bSP-inhibin" described and isolated by Chari et al. (1978).

Since the gonadotrophin-inhibiting activities in seminal plasma from intact and vasectomized bulls have the same properties, so far as they have been studied, and are present in the same amount, we suggest that they are due to the same protein material and have the same origin. The activity in the seminal plasma of the vasectomized bulls cannot have arrived from the testis by way of the vas deferens, and so cannot be due to inhibin which has escaped absorption from the rete testis fluid at the epididymis.

Although we cannot exclude the possibility that some inhibin may be present in bull seminal plasma, it seems certain that bull seminal plasma does contain gonadotrophin-inhibiting activity which is not, at least directly, of testicular origin.

This work was supported by the Medical Research Council of New Zealand and an award to J.C.P. by the University Grants Committee of New Zealand. We thank Dr A. F. Parlow for providing the reagents made available by the NIAMDD Rat Pituitary Hormone Distribution Program.

\section{References}

Amatayakul, K., Ryan, R., Uozumi, T. \& Albert, A. (1971) Reinvestigation of testicular-anterior pituitary relationships in the rat. $I$. Effects of castration and cryptorchidism. Endocrinology 88, 872-880.

Baker, H.W.G., Bremner, W.J., Burger, H.G., de Kretser, D.M., Dulmanis, A., Eddie, L.W., Hudson, B., Keogh, E.J., Lee, V.W.K., \& Rennie, G.C. (1976) Testicular control of follicle-stimulating hormone secretion. Recent Prog. Horm. Res. 32, 429-476.
Blanc, M.R. \& Dacheux, J.L. (1976) Existence of inhibin activity in the ram rete testis fluid: effect of physiological doses on plasma LH and FSH. Int. Res. Comm. Syst. 4, 460.

Chari, S. (1977) Chemistry and physiology of inhibin-a review. Endokrinologie 70, 99-107.

Chari, S., Duraiswami, S. \& Franchimont, P. (1978) Isolation and characterisation of inhibin from bull seminal plasma. Acta endocr., Copenh. 87, 434-448. 
Chari, S., Hopkinson, C.R.N., Fritze, E., Sturm, G. \& Hirschhauser, C. (1977) Partial purification of inhibin from testicular extracts. Acta endocr., Copenh., Suppl. 212, 381, Abstr.

Davies, R.V., Main, S.J., Young, M.G.W.L. \& Setchell, B.P. (1976) Bioassay of inhibin-like activity in rete testis fluid and its partial purification. J. Endocr. 68, $26 P$, Abstr.

Debeljuk, L., Arimura, A. \& Schally, A.V. (1973) Pituitary and serum FSH and LH levels after massive and selective depletion of the germinal epithelium in the rat testis. Endocrinology 92, 48-54.

Franchimont, P. (1974) Human gonadotrophin secretion in male subjects. In The Endocrine Function of the Human Testis, Vol. I pp 439-458. Eds V.H.T. James, M. Serio \& L. Martini. Academic Press, New York.

Franchimont, P., Chari, S. \& Demoulin, A.J. (1975a) Hypothalamus-pituitary-testis interaction. $J$. Reprod. Fert. 44, 335-350.

Franchimont, P., Chari, S., Hagelstein \& Duraiswami, S. (1975b) Existence of a follicle-stimulating hormoneinhibiting factor 'inhibin' in bull seminal plasma. Nature, Lond. 257, 402-404.

Franchimont, P., Chari, S., Hagelstein, M.T., Debruche, M.L. Duraiswami, S., Walton, J. \& Waites, G.M.H. (1976) Existence of a follicle-stimulating hormoneinhibiting factor in ram rete testis fluid. Andrologia $\mathbf{8}$, Suppl. 1, 127-128.

Gomes, W.R., Hall, R.W., Jain, S.K. \& Boots, L.R. (1973) Serum gonadotrophin and testosterone levels during loss and recovery of spermatogenesis in rats. Endocrinology 93, 800-809.

Hopkinson, C.R.N., Fritze, E., Chari, S., Sturm, G. \& Hirschhauser, C. (1977) Interaction between testosterone and an inhibin preparation in male rats. Int. Res. Commun. Syst. 5, 83, Abstr.

Keogh, E.J., Lee, V.W.K., Rennie, G.C., Burger, H.G., Hudson, B. \& de Kretser, D.M. (1976) Selective suppression of FSH by testicular extracts. Endocrinology 98, 997-1004.
Le Lannou, D. \& Chambon, Y. (1977) Présence dans l'épididyme d'un facteur abaissant fortement le taux sanguin de FSH chez le rat. C. r. Séanc. Soc. Biol. 171, 636-638.

Lugaro, G., Casellato, M.M., Mazzola, G. Fachini, G. \& Carrea, G. (1974) Evidence for the existence in spermatozoa of a factor inhibiting the follicle stimulating hormone releasing hormone synthesis. Neuroendocrinology 15, 62-68.

McCullagh, D.R. (1932) Dual endocrine activity of the testis. Science, N.Y. 76, 19-20.

Moodbidri, S.B., Joshi, L.R. \& Sheth, A.R. (1976) Isolation of an inhibin-like substance from ram testis. Int. Res. Commun. Syst. 4, 217.

Nandini, S.G., Lipner, H. \& Moudgal, N.R. (1976) A model system for studying inhibin. Endocrinology $\mathbf{9 8}$, $1460-1465$.

Peek, J.C. \& Watkins, W.B. (1978) Antigonadotrophic activity in bull seminal plasma-is it inhibin? N.Z. Med.J. 87, 105, Abstr.

Rich, K.A. \& de Kretser, D.M. (1977) Effect of differing degrees of destruction of the rat seminiferous epithelium on levels of serum follicle stimulating hormone and androgen binding protein. Endocrinology 107, 959-968.

Setchell, B.P. \& Jacks, F. (1974) Inhibin-like activity in rete testis fluid. J. Endocr. 62, 675-676.

Steinberger, A. \& Steinberger, E. (1976) Secretion of an FSH-inhibiting factor by cultured Sertoli cells. Endocrinology 99, 918-921.

Swerdloff, R.S., Walsh, P.C., Jacobs, H.S. \& Odell, W.D. (1971) Serum LH and FSH during sexual maturation in the male rat: effect of castration and cryptorchidism. Endocrinology 88, 120-128. 